\title{
The Impact of His Frequency and Religiosity toward Prolonged Second Stage and its Impact of the Placenta Separation in Maternity at Siti Fatimah Hospital Makassar
}

\author{
Sumarni Marwang ${ }^{1}$, Masni Masni $^{2}$, Stang Stang ${ }^{2 *}$, Anwar Mallongi $^{3}$, Jumrah Sudirman $^{4}$, Nurhidayat Triananinsi $^{4}$ \\ ${ }^{1}$ Midwifery Study Program, Megarezky University, Makassar, Indonesia; ${ }^{2}$ Biostatistic Department, Faculty of Public Health, \\ Hasanuddin University, Makassar, Indonesia; ${ }^{3}$ Department of Environmental Health, Faculty of Public Health, Hasanuddin \\ University, Makassar, Indonesia; ${ }^{4}$ Midwife Profession Study Program, Megarezky University, Makassar, Indonesia
}

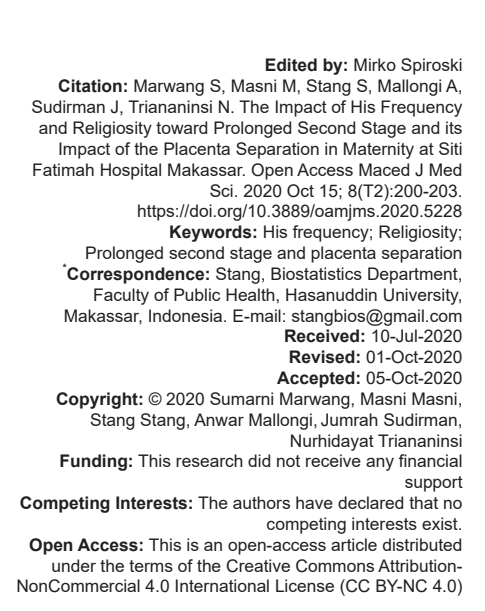

\section{Introduction}

Labor is a process of expulsion from the conception (fetus and URI) that has been enough months or can live outside the womb through the birth canal or other means by helping or without helping (own strength). While the labor of the second stage starting from the complete opening $(10 \mathrm{~cm})$ until the birth of the baby, the process takes 90 min in primigravida and 30 min in multigravida [1]. Principally, the delivery process is physiological, but there are still many labors that are accompanied by complications. The incidence of complications is still quite high, at $20 \%$ of the number of labor, but the number of obstetric cases handled is still below $10 \%$ [2], [3].

Maternal mortality is an indicator of the success of health services, especially midwifery services. Obstetric complications are very influenced by maternal mortality rates (MMR), including prolonged parturition (the length of the second stage) [4], [5], [6]. By maternal mortality rate of $34-45 \%$ results from bleeding, around
$1-3 \%$ incidence of post-partum hemorrhage due to placental retention. Placental retention is a cause of obstetric morbidity. It is diagnosed when the placenta fails to separate spontaneously during the third stage of labor when a mother experiences excessive bleeding without placenta separation. This causes post-partum hemorrhage and surgery [7], [8].

The process of labor for the prolonged second stage was very influenced by various factors including passage (birth canal/vaginal labor), power such as his (contraction of the uterine muscles and psychological factors from mother) including the form of husband support and religiosity [9], [10]. While factor of the baby are, passenger (fetus and placenta) and a factor of helper [11]. When prolonged labor of the second stage is not treated quickly, it will cause prolonged fatigue and dehydration so that it will impact on uterine contractions when removing the placenta and eventually cause disruption of placenta separation. The placenta is not separated during 30 min after newborn; there will be retention of the placenta, and eventually, cause postpartum hemorrhage so that it can cause the mother 
death. This research is conducted in which health and normal factors result in the labor process will take place spontaneous [12].

\section{Materials and Methods}

This study used observational analytic research in a cross-sectional study design. Exogenous variable was the frequency of his and religiosity. The endogenous variables were the Prolonged Second Stage and placental separation. Furthermore, carried out the analysis of impact independent variable (exogenous) and dependent variable (endogenous). This research was conducted at Siti Fatima Mother and Children Hospital of Makassar, South Sulawesi.

The population in this study was all mothers who gave birth or labor at Siti Fatima Mother and Children Hospital of Makassar when the study was running. The total sample in this study was some of the mothers who gave birth at Siti Fatima Mother and Children Hospital of Makassar; they were 60 respondents as a sample. Furthermore, the analysis used was path analysis to establish the exact paths traversed by exogenous variables to affect endogenous variables using path analysis computerized system with SPSS version 22.00 .

\section{Results}

The results of the bivariate analysis were conducted to find out whether there was an impact between exogenous variables on endogenous. The results of the analysis used path analysis were as follows:

Table 1 showed that there was an impact of his frequency on the prolonged second stage with a value of $p=0.046$, it was smaller than $\alpha=0.05$, it can be concluded that there was an impact of his frequency on the prolonged second stage and the effect was -0.259 .

Table 1: The impact of determinant factors toward prolonged second stage at Siti Fatimah Mother and Children Hospital of Makassar

\begin{tabular}{llll}
\hline Exogenous variable & $\begin{array}{l}\text { Standardized coefficients } \\
\text { beta }\end{array}$ & $\mathrm{t}$ & Sig. \\
\hline (Constanta) & & 0.504 & 0.616 \\
Frequency of His & -0.259 & -2.045 & 0.046 \\
Religiosity (Islamic) & -0.290 & -2.139 & 0.037 \\
\hline
\end{tabular}

Statistical test results on religiosity with a value of $p=0.037$ was smaller than $\alpha=0.05$, it can be concluded that there was an impact of religiosity prolonged second stage with the value and magnitude of the impact of -0.290 . Negative impact indicated that the better the level of religiosity, the less prolonged the second stage.
Table 2 showed that there was an impact of the prolonged second stage on placenta separation with $p=0,000$. The positive effect showed that the more time needed for the prolonged second stage, the longer time needed for placenta separation. The result of the statistic test on his frequency with $p=0.313$ was larger than $\alpha=0.05$, it can be concluded that his frequency did not have a direct influence of the placenta separation.

Table 2: Impact of each exogenous variable direct on placenta separation at Siti Fatimah Mother and Children Hospital of Makassar

\begin{tabular}{llll}
\hline Exogenous variable & $\begin{array}{l}\text { Standardized coefficients } \\
\text { beta }\end{array}$ & $\mathrm{t}$ & $\mathrm{Sig}$ \\
\hline (Constanta) & - & 0.411 & 0.682 \\
Frequency of His & -0.121 & -1.019 & 0.313 \\
Religiosity (Islamic) & 0.001 & 0.011 & 0.991 \\
Prolonged second stage & 0.51 & 4.166 & 0.000 \\
\hline
\end{tabular}

The result of the statistic test on religiosity with $p=0.991$ was larger than $\alpha=0.05$, it can be concluded that religiosity did not have a direct influence on the separation of the placenta.

Table 3 showed that the frequency of his had the largest indirect effect on placental separation (through the prolonged second stage) of -0.132 or $-13.2 \%$. Statistic test results on religiosity had the largest indirect effect on the placenta separation through a prolonged second stage of only -0.148 or only $-14.8 \%$.

Table 3: The largest impact exogenous variable indirect on placenta separation through prolonged second stage at Siti Fatimah Mother and Children Hospital of Makassar

\begin{tabular}{lll}
\hline Exogenous variable & $\begin{array}{l}\text { Multiple of Standardized coefficient (beta) } \\
\text { and variable of prolonged second stage }\end{array}$ & $\begin{array}{l}\text { large Indirect } \\
\text { impact }\end{array}$ \\
\hline Frequency of His & $-0.259 \times 0.51$ & -0.132 \\
Religiosity (Islamic) & $-0.290 \times 0.51$ & -0.148 \\
Prolonged second stage & 0.51 & \\
\hline
\end{tabular}

\section{Discussion}

The arising of his is an indication of the start of labor, if his arising was weak, short, and the consequences were rare, it will affect the decline of the head and cervical opening which is often called as coordinating uterine muscle contractions, finally it will affect the labor process of the prolonged second stage. It caused fatigue in the mother so that it will affect the contraction of the uterus in the process of the placenta separation [13], [14].

The results of the first hypothesis test were the frequency of his had an impact on the prolonged second stage with $p=0.046$, the frequency of his had no direct effect on placenta separation with a value of $p=0.313$ and so did the frequency of his had the largest indirect effect on placenta separation through the prolonged second stage of -0.132 or only $-13.2 \%$.

The arising of his is an indication of labor start, if his arise was not strong and regular, it would have impacted the process of the head down and the 
opening of the cervix would ultimately affect the labor process, especially in the prolonged second stage and finally experienced long parturition [15]. The prolonged second stage will cause fatigue in the mother, so it again influenced uterine contractions when the placenta was separated [16].

Serenity (calmness) in facing childbirth (labor) is needed by every mother. One of the efforts to avoid excessive anxiety is to increase their religiosity. The role of religion is required to overcome the level of anxiety in facing childbirth [17]. Stress in facing childbirth/ labor would have an impact on his contractions so that prolonged labor. Mothers who experienced prolonged fatigue would have an impact on the process of placenta separation in the third stage [18], [19].

The results of the second hypothesis test were religiosity had an effect on the prolonged second stage with $p=0.037$. Religiosity did not have a direct effect on the placenta separation with a value of $p=0.991$ and religiosity had the largest indirect effect on the placenta separation through prolonged second stage only -0.148 or $-14,8 \%$.

According to researchers that the results of the hypothesis test were proven (significant) because someone who had good religiosity would obtain inner peace so that it did not induce the tension of smooth muscles and blood vessels, its manifestation in patients will experience the prolonged second stage which was relatively safe [20].

The result of the fifth hypothesis test showed that prolonged second stage had an influence on the placenta separation with a value of $p=0,000$. The impact of the prolonged second stage on the separation of the placenta was positive; it meant that the longer time needed for the second stage, the longer time needed for placental separation.

According to researchers that the results of the hypothesis test were proven (significant) because labor in the prolonged second stage could cause weak uterine contractions due to the prolonged fatigue so that it can have an impact to the detachment process of the placenta or slowdown in the process of the placenta separation [15]. With the presence of uterine muscle retraction, the placenta was separated to its attachment in the Nitabuch layer. The entire placenta is separated within $15 \mathrm{~min}$, pushed toward the vagina, and will be born spontaneously or with a slight push from above the symphysis. His frequency is getting lower, but can still survive so that the blood vessels were pinched. Separation and removal of the placenta as if squeezed from the uterine fundus into opened cervix [21], [22].

\section{Recommendation}

It is expected that top management can make policies related to the determinants of the prolonged second stage of labor and its impact on placenta separation in maternity at Siti Fatimah Mother and Children Hospital.

\section{References}

1. A Guide to Obstetrical Coding. SF.

2. World Health Organization. World Health Organization Recommendations. Geneva: World Health Organization; 2014. p. 1-64.

3. Abdullah T, Arundhana Al, Manyullei S. The effect of counselling intervention during antenatal care on the knowledge and attitude about danger signs in pregnancy: A cross-sectional study in Takalar regency. 2020;1-5

4. Yogev Y, Melamed N, Bardin R, Tenenbaum-Gavish K, BenShitrit G, Ben-Haroush A. Pregnancy outcome at extremely advanced maternal age. Am J Obstet Gynecol. 2010;203(6):558. e1-7. https://doi.org/10.1016/j.ajog.2010.07.039 PMid:20965486

5. Cegolon L, Mastrangelo G, Heymann WC, Dal Pozzo G, Ronfani L, Barbone F. A systematic evaluation of hospital performance of childbirth delivery modes and associated factors in the Friuli Venezia Giulia Region (North-Eastern Italy), 2005-2015. Sci Rep. 2019;9:19442. https://doi.org/10.1038/ s41598-019-55389-z

PMid:31857615

6. Sudirman J, Sinrang AW, Marwang S, Nurlaily A, Sabar S, Astuti AT, et al. The analysis estradiol levels against sexual desire in perimenopause women in Makassar, South Sulawesi, Indonesia. Enferm Clin. 2020;30(Suppl 2):350-3. https://doi. org/10.1016/j.enfcli.2019.07.117

PMid:32204184

7. Perlman NC, Carusi DA. Retained placenta after vaginal delivery: Risk factors and management. Int $\mathrm{J}$ Womens Health. 2019;11:527-34. https://doi.org/10.2147/ijwh.s218933 PMid:31632157

8. Urner F, Zimmermann R, Krafft A. Manual removal of the placenta after vaginal delivery: An unsolved problem in obstetrics. J Pregnancy. 2014;2014:274651. https://doi. org/10.1155/2014/274651

PMid:24812585

9. Dewl RK, Budihastuti UR, Pamungkasari EP. Biopsychosocia factors associated with postpartum haemorrhage in Surakarta, Central Java. J Matern Child Health. 2018;3(3):207-15. https:// doi.org/10.26911/thejmch.2018.03.03.05

10. Banõs N, Migliorelli F, Posadas E, Ferreri J, Palacio M. Definition of failed induction of labor and its predictive factors: Two unsolved issues of an everyday clinical situation. Fetal Diagn Ther. 2015;38(3):161-9. https://doi.org/10.1159/000433429 PMid:26138441

11. Begley CM, Gyte GM, Devane D, McGuire W, Weeks A, Biesty LM. Active versus expectant management for women in the third stage of labour. Cochrane Database Syst Rev. 2019;2(2):CD007412. https://doi.org/10.1002/14651858. cd007412.pub5

PMid:30754073

12. Jansen L, Gibson M, Bowles BC, Leach J. First do no harm: Interventions during childbirth. J Perinat Educ. 2013;22(2):8392. https://doi.org/10.1891/1058-1243.22.2.83 PMid:24421601

13. Hanghøj S. When it hurts I think: Now the baby dies. Risk perceptions of physical activity during pregnancy. Women Birth. 
2013;26(3):190-4. https://doi.org/10.1016/j.wombi.2013.04.004 PMid:23711581

14. Labor S, Maguire S. The pain of labour. Rev Pain. 2008;2(2):159. https://doi.org/10.1177/204946370800200205 PMid:26526404

15. Nott JP, Bonney EA, Pickering JD, Simpson NA. The structure and function of the cervix during pregnancy. Transl Res Anat. 2016;2:1-7. https://doi.org/10.1016/j.tria.2016.02.001

16. Lothian JA. Saying "No" to induction. J Perinat Educ. 2006;15(2):43-5. https://doi.org/10.1624/105812406×107816

17. Ghodrati F, Mokhtaryan T, Akbarzadeh M. Effect of pregnancyrelated religious training on religious attitudes among pregnant women. J Midwifery Reprod Health. 2018;6(3):1296-304.

18. Storksen HT, Eberhard-Gran M, Garthus-Niegel S, Eskild A. Fear of childbirth; The relation to anxiety and depression. Acta Obstet Gynecol Scand. 2012;91(2):237-42. https://doi. org/10.1111/j.1600-0412.2011.01323.x

PMid:22085403

19. Haring M, Smith JE, Bodnar D, Misri S, Little RM, Ryan D. Coping with anxiety during pregnancy and following the birth. BC Ment Health Addict Serv. 2013.

20. Care J, Bolton MJ, Carlson T, Holowick-sparkes C, Matthews C. Calm in the Storm: Coping with the Stresses of Life. Winnipeg, MB, Canada: Klinic Community Health; 2013.

21. Chamley LW, Holland OJ, Chen Q, Viall CA, Stone PR, Abumaree M. Review: Where is the maternofetal interface? Placenta. 2014;35:S74-80. https://doi.org/10.1016/j. placenta.2013.10.014

PMid:24239157

22. Nurhikmah, Abdullah T, Arundhana Al, Stang, Manyullei S. The roles of responsive and empathy of midwives in antenatal care visit of pregnant women in pangkepregency. 2020:1-45. 